\title{
Imagens do negro na literatura infantil brasileira: análise historiográfica*
}

Maria Cristina Soares de Gouvêa

Universidade Federal de Minas Gerais

Correspondência:

Maria Cristina Soares de Gouvêa

Rua Grão Pará, 981 apto. 903

30150-341 - Belo Horizonte - MG

e-mail: cristi@fae.ufmg.br

\section{Resumo}

0 artigo analisa as representações sociais sobre o negro presentes na produção literária destinada à criança no Brasil, nas três primeiras décadas do século XX. A definição de tal periodização tem em vista a emergência, a partir da década de 1920, na produção artística e científica nacionais, da discussão em torno da identidade brasileira. Destaca-se a construção de referências estéticas e científicas voltadas para compreensão dos significados da composição racial da população, temática que ecoa nas obras endereçadas ao público infantil.

Se nas obras produzidas até a década de 1920 os personagens negros eram ausentes ou remetidos ao recente passado escravocrata, observa-se um deslocamento: os personagens negros tornam-se freqüentes, descritos de maneira a caracterizar uma suposta integração racial, hierarquicamente definida. Mediante a descrição das características físicas e cognitivas dos personagens negros, de sua relação com os personagens brancos, sua inserção no espaço social, configura-se uma visão da temática racial endereçada ao público infantil. Os negros aparecem como personagens estereotipados, descritos a partir de referências culturais marcadamente etnocêntricas que, se buscam construir uma imagem de integração, o fazem a partir do embranquecimento de tais personagens.

$\mathrm{Na}$ verdade, mais que embranquecer os personagens, a literatura infantil do periodo dirige-se e produz um leitor modelo identificado com os personagens e as referências culturais brancas, marcando, portanto, um embranquecimento do leitor.

\section{Palavras-chave}

História - Literatura - Infância - Raça.

* Texto apresentado no XXIII Congresso do ISCHE (International Society Conference of History of Education), Alcalá de Henares, Espanha, 2000. 


\section{Images of the Black in children's literature in Brazil: historiographical analysis*}

Maria Cristina Soares de Gouvêa

Universidade Federal de Minas Gerais

Contact:

Maria Cristina Soares de Gouvêa

Rua Grão Pará, 981 apto. 903

30150-341 - Belo Horizonte - MG

e-mail: cristi@fae.ufmg.br

*The present work was presented in the XXIII Congress do ISCHE (International Society Conference of History of Education), Alcalá de Henares, Espanha, 2000.

\begin{abstract}
The article analyzes the social representations about the Black present in the literary production for children in the first three decades of the 20th century in Brazil. The definition of such period takes into account the emergence, from the 1920s, of the discussion around the issue of the Brazilian identity in the national literary and artistic production. Of special relevance is the construction of aesthetic and scientific references aimed at understanding the meanings of the racial composition of the population, a theme that reverberates in the works addressed to the children.

If in the works produced up to the 1920s black characters were absent or referred to the then recent slavery past, a shift can now be observed. Black characters become frequent, described in such a manner as to characterize a supposed, hierarchically defined, racial integration. Through the description of the physical and cognitive features of the black characters, of their relation to white characters, and their insertion in the social sphere, a vision of the race issue addressed to children is composed. Blacks appear as stereotyped characters, described from markedly ethnocentric cultural perspectives that, even when trying to build an image of integration, do it from the whitening of the characters.

Actually, more than whitening the characters, children's literature of the period addresses and shapes a model reader identified with the white characters and cultural references signaling, therefore, to the whitening of the reader.
\end{abstract}

\section{Keywords}

History - Literature - Infancy - Race. 
0 século $X X$ foi insistentemente proclamado e celebrado como o "século da criança". É inegável a centralidade que a infância assumiu na cultura contemporânea, a ela sendo direcionado todo um mercado de bens simbólicos alicerçados na idéia da sua singularidade e distinção em relação ao adulto. Embora a afirmação da especificidade da infância resulte de uma longa construção histórica, foi no século passado que ganhou contornos mais precisos e definidos, tornando-se alvo de um conjunto de políticas de proteção e amparo e, por outro, de uma maciça produção cultural.

A literatura infantil, concebida como diferenciada da produção destinada ao leitor adulto, funda-se em tal concepção. A construção do "gênero" só se fez possível em uma cultura que conferiu a leitor infantil uma especificidade, a qual demandaria um texto próprio. Ao longo do processo histórico de elaboração da literatura infantil, os autores não apenas produziram a identidade do "gênero",' mas conformaram uma identidade do leitor. $\mathrm{Ou}$ seja, ao definir e qualificar a singularidade dessa produção literária, produziu-se também uma representação de infância e leitor infantil.

De maneira característica, a literatura infantil definiu-se historicamente pela formulação e transmissão de visões de mundo, assim como modelos de gostos, ações, comportamentos a serem reproduzidos pelo leitor. Construiuse a concepção de um texto literário em que o caráter pedagógico fez-se especialmente presente. Ao mesmo tempo, à menoridade da infância associou-se a menoridade da produção literária, no interior desse campo cultural.

Para além de sua especificidade e à semelhança da literatura destinada ao público adulto, a escrita literária guarda com a realidade à qual se refere uma relação, não de transparência, mas de reconstrução. 0 autor, no momento da produção do texto, traduz na escrita a sua compreensão do real, como também o projeto de realidade que se quer conformar por meio da narrativa, ou como define Leila Perrone-Moysés (1990): “a reconstrução do mundo pelas palavras".
Considerando que a literatura constitui um campo de produção, circulação e apropriação cultural, seu estudo tem sido fonte importante para a investigação histórica. No trabalho historiográfico, a literatura tem sido ferramenta de apreensão da dinâmica sociocultural de diferentes momentos históricos. Porém, há que se destacar a especificidade da fonte e a importância de o historiador tomar o texto literário não como descrição do real, mas como sua representação. Representação esta constituída no diálogo com as demais práticas culturais, que conferem à prática literária sua sustentação.

Com essa perspectiva de análise, tendo como objeto compreender a representação da infância nas primeiras décadas do século XX, tomei a produção literária destinada à criança, nesse período como fonte, de maneira a apreender os discursos sobre a infância em circulação, naquele momento histórico. A definição do recorte temporal alicerçou-se no fato de que, nesse momento, a produção literária dirigida ao leitor infantil experimentou não apenas uma expansão significativa de títulos (Lajolo; Zilberman, 1985), mas também uma mudança nos cânones que regiam tal produção. Mudança esta produzida no diálogo com as transformações experimentadas nas práticas culturais mais amplas.

Foram analisados dezessete títulos, selecionados a partir de sua circulação. ${ }^{2}$ Ou seja, na definição do corpus da pesquisa foi usado como critério o estudo de obras que tiveram mais de uma edição ao longo do período analisado e que eram referidas em estudos sobre a história da literatura infantil brasileira (Coelho, 1981; Lajolo; Zilberman, 1985; Fraccaroli, 1953).

Se meu intuito era investigar a produção de modelos de infância nas obras, novas questões emergiram ao longo do estudo. Os textos indicaram temáticas que dialogavam diretamente

1. Para Marisa Lajolo e Regina Zilberman (1985) talvez a literatura infantil defina-se nem tanto por uma especificidade literária propriamente dita, mas pela construção de mecanismos próprios de produção e circulação dos textos. 2. Obras consultadas no final do texto. 
com as reflexões presentes nas práticas culturais dirigidas ao adulto durante aquele periodo histórico. Destaca-se aí a discussão acerca da identidade brasileira, racialmente recortada. A partir da constatação da centralidade da temática racial nas narrativas, em que o negro era constantemente referido, optei por contemplar também no meu estudo as representações sobre o negro presentes nos textos analisados, tema sobre o qual busco aqui refletir.

\section{A literatura infantil e a produção artística e científica}

No Brasil, é a partir das décadas de 20 e 30 do século $X X$, em consonância com o processo de modernização social, que a produção literária destinada a criança foi afirmada. A urbanização crescente, a exigir uma população identificada com os códigos citadinos, em que as práticas sociais de leitura se faziam necessárias, as reformas de ensino que tinham como um de seus pressupostos o desenvolvimento na criança do gosto pela leitura, a afirmação de uma família burguesa centrada nos cuidados à infância, em termos gerais, tornaram possível a consolidação de uma literatura voltada para o leitor infantil.

Tal produção trazia as marcas da interlocução com as práticas culturais mais amplas, em que ao processo de modernização da sociedade brasileira aliava-se a construção de uma linguagem que expressasse a complexidade da vida contemporânea. À medida que a sociedade brasileira vivia, principalmente nos centros urbanos, a transformação das estruturas sociais tradicionais herdadas do regime monárquico, experimentavase um sentimento de perplexidade e de ausência de referências culturais ante a uma nova ordem, que então apenas se desenhava. A experiência de desenraizamento do homem moderno fez brotar uma tentativa de compreensão e organização perante o novo. Nesse sentido, no Brasil, tomou forma a investigação acerca da identidade brasileira, através da recuperação de suas raízes, de forma a situar-se num universo desprovido de referências. Como afirma Sevcenko:
Essa busca pelo popular, o tradicional, o local e o histórico não era tida como menos moderna, indicando, muito ao contrário, uma nova atitude de desprezo pelo europeísmo embevecido convencional e um empenho para forjar uma consciência soberana, nutrida em raizes próprias, ciente de sua originalidade virente e confiante num destino de expressão superior (...) introduzir novos laços, a pretexto de resgatar elos, seria uma forma de forjar vínculos simbólicos que substituíssem nexos sociais e políticos que os novos tempos e suas condições haviam corroído. (1992, p. 237)

Delineou-se um novo olhar para o país que permitisse compreendê-lo como nação com uma identidade própria, a chamada "brasilidade". Destacam-se uma série de produções artísticas e científicas do período, voltadas para compreender o que é o brasileiro, o que o singulariza e o define, e que marcas essa identidade imprimia à cena social. Em formações discursivas diferenciadas a discussão em torno da identidade brasileira ocupou a cena, assumindo contornos e leituras marcadas pela pluralidade. Observa-se na produção simbólica do período, tanto a exaltação da brasilidade como a atribuição do atraso do país à sua composição étnicocultural. Ou seja, a temática da identidade brasileira assumiu contornos próprios em diferentes formações discursivas nos campos cultural e científico e, mesmo em cada campo de produção simbólica, foi diversamente apreendida.

Buscou-se, no interior do campo artístico-cultural, formular uma linguagem e referências estéticas que simbolizassem a experiência de modernização da sociedade brasileira. O Movimento Modernista no Brasil constituiu-se, por um lado, a partir do diálogo com as diversas expressões da vanguarda cultural européia. Por outro, tinha como fator aglutinador buscar, nas origens e singularidades da cultura nacional, referências estéticas para a produção de uma linguagem identificada com a brasilidade. 
No campo científico, construíram-se diferentes discursos em torno da compreensão das origens da sociedade brasileira, quer numa perspectiva de intervenção cientificista, quer de análise de sua singularidade. Ou seja, se a questão definidora em ambos os campos era a inserção na modernidade por meio da compreensão da brasilidade, tal temática teve diferentes traduções no interior de cada campo. Falava-se sobre o mesmo tema, porém com diferentes olhares e perspectivas de análise, levando a produções diferenciadas, geradoras de discursos e práticas singulares.

Época de intensa produção científica, na década de 1930 publicaram-se obras clássicas voltadas para compreensão da identidade brasileira, com destaque para análise do significado de sua composição racial. De um lado, Oliveira Vianna, com seus estudos fundados numa perspectiva de desqualificação do negro e defensora da miscigenação como estratégia para o embranquecimento da população. De outro, Gilberto Freyre que, em Casa-grande \&t senzala, ressignificou os estudos sobre as relações raciais brasileiras, apontando a positividade da cultura negra, embora numa perspectiva mitificadora. Ao utilizar o termo democracia racial, este tornaria-se referência para compreensão da problemática racial no país, inclusive no sentido do escamoteamento de suas tensões.

Nesse contexto, sob o signo da modernidade, a literatura infantil buscou definir sua identidade no interior da produção artística brasileira. As obras sustentavam-se no diálogo com os temas presentes nas demais produções culturais, como a identificação da brasilidade, embora, dada a especificidade de seu público, assumisse contornos próprios.

0 ícone da brasilidade traduziu-se, na literatura infantil brasileira, pela tentativa de construção de personagens e temáticas que recuperassem uma tradição oral presente no imaginário social do país e que, ao mesmo tempo, falasse sobre seu patrimônio cultural. Os autores buscaram no chamado folclore nacional referências temáticas e estéticas para cons- trução de um texto dirigido à criança. Desse modo, a temática racial torna-se constante nas obras escritas entre as décadas de 1920 e 1940, por meio da presença de personagens negros, associados às raízes culturais do país.

\section{O negro na literatura infantil: da ausência à mitificação}

Na produção literária das duas primeiras décadas do século $X X$ já havia uma preocupação com a nacionalização da produção. Porém, esta se traduzia em textos que falavam do país numa perspectiva marcadamente ufanista, que glorificavam as grandezas do nosso povo e da nossa terra, claramente identificados com a cultura européia. Tratava-se de desenvolver o sentimento de amor à pátria e, ao mesmo tempo, veicular um ideal civilizatório europeizado.

Porém, a partir da década de 1920, em consonância com as transformações experimentadas no campo cultural mais amplo, na produção cultural destinada ao público infantil busca-se falar do país remetendo-se a sua identidade cultural. Procurava-se escrever à criança brasileira na sua linguagem, sobre sua gente, suas raízes raciais e culturais. Tal temática tornou-se preocupação presente em grande parte dos autores voltados para esse público. A literatura infantil do período dialogava com as diversas representações construídas acerca da questão racial, estabelecendo uma interlocução com os discursos produzidos no campo científico e artístico, incorporando tal temática no interior das narrativas.

Ao se analisarem as obras literárias voltadas para o público infantil a partir da década de 1920, e procedendo-se a um estudo comparativo com a incipiente produção anterior, chama atenção o aparecimento do negro na narrativa.

Nos textos pesquisados, produzidos entre 1900 e 1920, o negro era um personagem quase ausente, ou referido ocasionalmente como parte da cena doméstica. Era personagem mudo, desprovido de uma caracterização que fosse além da referência racial. Ou então per- 
sonagem presente nos contos que relatavam o período escravocrata, como na obra: Contos pátrios, de Olavo Bilac e Coelho Neto, de 1906, em que os autores descrevem com ternura a figura submissa de Mãe Maria.

Essa ausência do negro nas cenas sociais descritas no período remete à sua marginalização após a abolição. 0 apagamento do negro nos textos da época reflete uma mentalidade dominante voltada para os ideais de progresso e civilização. Procuravam-se eliminar os antigos hábitos urbanos, assim como afastar dos grandes centros os grupos populares, concebidos como focos de agitação e resistência à nova ordem social. Nesse quadro, o negro era percebido como herdeiro de uma ordem social arcaica e ultrapassada, ligada ao tradicionalismo, à ignorância, ordem a ser substituída por um modelo europeizante, calcado na idéia de progresso. A escravidão era representada como marca vexatória do passado de um país atrasado. Assim, a figura do negro, com seu corpo, suas práticas e sua história constituiria a presença incômoda da antiga ordem escravocrata, incompativel com o projeto de um país "civilizado".

À medida que nas práticas culturais mais amplas desloca-se a discussão em torno da brasilidade, não mais de negação, mas de afirmação de sua composição racial, a representação do negro na literatura infantil alterase. 0 negro emergia nas narrativas, de maneira mitificada, identificado com as raízes do país. Cabe agora analisar as imagens construídas sobre o negro na produção analisada, a fim de compreender a representação que as relações raciais assumiam na literatura infantil.

\section{Contadores de histórias}

A negra e o negro velho transformaramse em personagem constantes, como agentes socializadores das crianças brancas, numa posição de servidão que revela a continuidade com o modelo escravocrata. Personagem sempre presente, mesmo que como coadjuvante, nas nar- rativas destinadas à criança do período, o negro surgia revestido de uma estereotipia que se repete basicamente em todos os textos analisados. 0 negro constituía personagem quase mítico, cuja inserção ao longo da narrativa destaca-se e diferencia-se dos demais personagens.

$\mathrm{Na}$ verdade, a questão da raça emerge de forma ambigua ao longo de tais narrativas. Por um lado, o negro vinha reafirmar a identidade nacional, associado ao folclore brasileiro e marcando com suas histórias, práticas religiosas e valores, a infância dos personagens. Por outro, esses mesmos valores não encontravam lugar no seio de uma sociedade que se pretendia moderna, fazendo-o ocupar um espaço social à parte. Enquanto a modernidade, associada à urbanidade, ao progresso, à técnica, e à ruptura, era representada pelos personagens brancos adultos, os negros era relacionados a significantes opostos, como tradição e ignorância, universo rural e passado.

Excluído do projeto de modernização do país, e afirmado estereotipicamente em sua identidade cultural constituidora da brasilidade, o negro assumia um espaço mítico ao longo da narrativa, negado em sua concretude, mas reificado e folclorizado no imaginário literário.

É principalmente a partir da década de 1930 que torna-se maciça a presença, na produção literária destinada à criança, de personagens negros, sobretudo como contadores de histórias, demonstrando a forte presença de traços associados à cultura negra, como a oralidade, a transmissão de histórias de origem africana. Tais histórias eram representadas como carregadas de valor afetivo, contadas por pretas velhas, associadas à ingenuidade, ao primitivismo, apresentando uma estereotipia e simplificação características.

É na perspectiva de resgate folclorizado das raizes nacionais que os contadores de história negros eram recuperados nas narrativas, como depositários de uma tradição situada no passado, a ser registrada e resgatada através da literatura infantil.

É interessante observar que Lobato em Histórias de Tia Nastácia ironizava impiedo- 
samente tal produção. Tia Nastácia foi convidada a contar suas histórias, porque:

- Tia Nastácia é o povo. Tudo que o povo sabe e vai contando de um para o outro ela deve saber. Estou com idéia de espremer Tia Nastácia para tirar o leite do folclore que há nela, afirma Pedrinho.

Ao ouvir essas histórias, as crianças reagiram, apontando as incoerências das narrativas orais. Na fala de Emília, esta explicitava:

- Só aturo estas histórias como estudo da ignorância e burrice do povo. Prazer não sinto nenhum. Não são engraçadas, não têm humorismo. Parecem-me muito grosseiras e bárbaras - coisa mesmo de negra beiçuda, como Tia Nastácia. Não gosto, não gosto e não gosto. (1937, p. 31)

Ante a reação das crianças diante de suas histórias, Tia Nastácia perdeu o posto de contadora, reassumindo seu lugar de cozinheira, sendo substituída por Dona Benta, que com auxílio dos livros, "sabe contar histórias de verdade".

Lobato apontava a contradição entre o projeto de resgate da tradição oral e sua inadequação ao presente, na medida em que era associada à ignorância e à falta de criatividade. Lobato falava do fim de uma tradição, sepultada pelos valores da modernidade, que, ambiguamente, de um lado buscava recuperar as raizes nacionais e, de outro, enxergava nessas raizes as origens da ignorância que impediriam a construção de um Brasil moderno.

Na visão de Dona Benta:

Nós não podemos exigir do povo o apuro artístico dos grandes escritores. 0 povo... Que é o povo? São essas pobres tias velhas, como Nastácia, sem cultura nenhuma, que nem ler sabem e que outra coisa não fazem senão ouvir as histórias de outras criaturas igualmente ignorantes, e passá-las para outros ouvidos, mais adulteradas ainda. (Lobato, 1937, p. 30)
A perspectiva de resgate de contos da tradição oral de diversos povos já aparecia em 1919, na coleção Biblioteca Infantil, quando Tales de Andrade lançou um volume com contos atribuídos ao folclore africano Flor encarnada. Neste conto, esta era uma princesa africana:

(...) tão inteligente e tão instruída que todas as pessoas vinham lhe pedir conselhos Ela sabia qual o remédio a dar aos doentes, conhecia todas as espécies de plantas. (...) Um dia Flor Encarnada ao passear encontrou uma linda moça, sentada junto de um algodoeiro. Era um jovem branca, de estranha beleza...

- Quem é você? perguntou Flor Encarnada cheia de admiração. Eu nunca a vi em nossas cabanas...

- É verdade, respondeu a moça, sorrindo. Embora você não me visse, era eu quem segredava aos seus ouvidos tudo o que você sabe em relação à floresta. Quem julga você que lhe tenha ensinado as coisas que você conhece das plantas e dos animais? Era eu quem lhe ensinava, menina...

(Andrade, 1919, p. 7-8)

Nota-se aí que se por um lado a publicação de histórias africanas revela uma suposta valorização daquela cultura, por outro, na história analisada, o saber do negro foi negado e atribuído a um personagem branco. Mesmo o conhecimento não letrado de práticas geralmente atribuídas ao saber africano foram, no texto, remetidas a personagem branco, destituindo-se o negro de um elemento fundamental de sua identidade.

No mesmo volume, o autor relatava a história de "Pérola da Manhã", a qual desejava atravessar um rio que a tornaria branca:

Tamil disse-nos que os primeiros homens que foram criados viviam à margem de um grande rio, que fica para lá!, disse Pérola da Manhã, apontando para o norte. Eram todos pretos. Mas, alguns deles que sabiam nadar, 
atravessaram o rio para o outro lado. A água lavou-os e eles ficaram brancos. Desde então, os homens brancos estão sempre a estender os braços, convidando os homens pretos a também atravessarem o rio (...) eu também desejava atravessá-lo nado, a fim de tornar-me branca. (Andrade, 1919, p. 32)

0 conto foi atribuído pelo autor ao folclore africano, mas tinha como temática o desejo de embranquecimento, de purificação do personagem através da negação de seu "pertencimento" racial. Ao atravessar o rio, os negros seriam lavados, ou seja, despojados e limpos de seu fardo racial. Percebe-se assim a visão racista e etnocêntrica do conto, atribuindo à natureza do negro um sentimento de inferioridade racial e um desejo de embranquecimento, que estariam presentes na própria cultura africana e não seriam fonte da desqualificação vivida no contato com a cultura branca. Assim, o negro seria naturalmente inferior, almejando sempre embranquecer-se para aprimorar-se. 0 projeto de resgate da cultura africana foi construído a partir do olhar do narrador branco, cujos valores estavam impressos na narrativa. Tal texto exemplifica a contradição presente nas demais produções dirigidas à criança, em que a caracterização da cultura negra era focalizada a partir de um referencial etnocêntrico, o qual tomava a cultura branca européia como intrínsecamente superior.

\section{Pretos e pretas velhas}

Nos textos analisados, os personagens negros presentes nas narrativas do período eram invariavelmente descritos como: a negra velha, a preta velha, o preto velho, ou crianças negras que partilhavam, mesmo que numa posição social servil, o cotidiano das crianças brancas. De todas as narrativas investigadas, o negro ou negra jovem eram absolutamente ausentes, revelando uma exclusão social característica do período. 0 negro jovem era percebido como potencialmente perigoso, fonte de agitação, insubordinação ou vagabundagem. 0 resgate que se pretendia nas narrativas, tanto endereçadas ao público infantil quanto ao adulto, não era o do negro concreto, marginalizado do processo de modernização. Situado no passado, o negro era representante de uma relação marcada por subserviência e docilidade.

Novamente é Lobato quem, de maneira "cruel", fez referência a essa representação em seu texto. Em Memórias da Emília, esta ao relatar ao Anjinho caído do céu que a vaca era um animal precioso para o homem e que, no entanto, o termo "vaca" era usado de forma depreciativa, na linguagem cotidiana, comentava:

Pois muito bem. A vaca é tudo isso que acabo de dizer e muito mais. No entanto, se você comparar a mais suja negra de rua com uma vaca dizendo: "Você é uma vaca", a negra rompe num escândalo medonho e se estiver armada de revólver, dá tiro. (1936, p. 14 - grifo meu)

Nos textos analisados, esta constituiu a única referência ao negro da cidade, situado no presente - a negra suja de rua, armada de revólver, pronta a fazer um escândalo. Revela-se aí a descontinuidade entre a representação da negra velha, afetiva e subserviente, e a negra de rua, escandalosa e insolente. Estabelece-se uma oposição semanticamente expressa entre a negra de rua versus a negra velha da roça. 0 resgate mitificado do passado aliava-se à negação e exclusão no presente, no retrato do negro na literatura infantil.

0 negro e a negra velha da roça eram remetidos na literatura infantil a um espaço geograficamente situado à margem, não inseridos nas relações urbanas, mas habitantes de um locus simbólico distante, remanescente de um Brasil agrário que se queria ora resgatar, ora sepultar. Os negros habitavam as tocas nos confins do mato onde persistiam com suas crenças, enquanto viviam e faziam sobreviver suas tradições, como as práticas religiosas, vistas como feitiçaria pelos personagens brancos. 
A representação da feitiçaria associada ao negro repete-se ao longo de todas as narrativas. A feitiçaria não se mostrava uma prática presente, mas remanescente nas figuras daqueles pretos e pretas velhas que habitavam, isolados, suas taperas. Menotti Del Pichia, em $O$ país das formigas, e Lobato, em $O$ saci, assim afirmavam:

Havia uma cabana escondida numa porção de árvores. Todos os que passavam por lá se benziam. É que corria a fama por toda a redondeza que ali morava um feiticeiro. De fato, o dono daquela cabana era um preto velho, muito feio, muito misterioso. (Del Pichia, 1932, p. 7)

- Pois seu Pedrinho é uma coisa que branco da cidade nega, diz que não há, mas há. Não existe negro velho por aí, desses que nascem e morrem no meio do mato, que não jure ter visto Saci. Nunca vi, mas sei de quem viu... o Tio Barnabé, fale com ele. Negro sabido tá aí! Entende de todas as feitiçarias - disse Tia Nastácia. (Lobato, 1921, p. 23)

Verifica-se aí a incorporação, no espaço da literatura infantil, de uma representação do negro relacionado a práticas religiosas “primitivas”, "pagãs”. A cultura e a tradição negras eram compreendidas como manifestação de uma cultura inferior, pré-científica, corpori-ficada nos pretos e pretas velhas, os assim chamados feiticeiros. Esses eram descritos como possuidores de um saber que não encontrava lugar numa sociedade que buscava modernizar-se, sob a égide de uma lógica científica que recusava tais manifestações.

Os brancos, nas narrativas, não eram descritos reprimindo ou temendo tais práticas, mas percebiam-nas como manifestações de um primitivismo cognitivo. No livro Férias com a vovó de Maria Velloso, lê-se o seguinte diálogo entre a negra cozinheira Jovita e as crianças brancas:
Ora, disse Adolfo, você não vê logo que ela deixava passar do ponto o doce e que só por isso ele queimava? Jovita: - Credo, menino! Você não acredita em nada! Pois eu me lembro dessa pequena; ela chorava que fazia pena, dizia que a borboleta tinha vindo botar quebranto nela. Adolfo não quis brigar com a velha e calou-se, as meninas piscaram um olho e abafaram uma risadinha, mas Vera e Marcelo estavam um tanto assombrados. Vera: - Ó Jovita, ainda há encantos? Jovita: - Se há! Se ainda há feitiçaria? Oh! gente! Não é tão longe assim! Ali mesmo no caminho do córrego mora a Tia Eva. Dizem que ela é uma bruxa... A mulata afastou-se resmungando. Ficando sós, os pequenos começaram a rir. Sabiam bem que os feitiços só existem na cabeça de algumas pessoas, mas mesmo assim deu-lhes vontade de ir passear por perto do casebre encantado. Os dois pequenos não sabiam o que pensar, nem o que havia de certo naquilo tudo! Vera principalmente que gostava tanto de histórias de fadas!... (Velloso, 1932, p. 147)

É interessante como no texto faz-se presente uma representação que associava o negro à criança pequena, como se ambos estivessem no mesmo nível de desenvolvimento cognitivo. 0 negro seria como uma criança grande, com uma mentalidade infantil que a criança branca pequena demonstraria. Tal visão traduz uma produção científica do final do século XIX e início do século XX, que associava o raciocínio dos povos ditos primitivos ao pensamento infantil, ambos marcados por uma incapacidade de acesso ao raciocínio lógico formal, característico do adulto civilizado (Nina Rodrigues, 1935; Gerken; Gouvea, 2000). Na narrativa analisada, eram as crianças pequenas que impressionavam-se com a fala de Jovita, visto que ambas possuiriam o mesmo nível de desenvolvimento mental. A estas se oporiam as crianças brancas maiores, representantes de uma lógica que recusava a idéia de encanto e 
feitiçaria, e olhavam com desdém e benevolência a manifestação dessas concepções, tanto na negra adulta quanto nas crianças menores.

\section{Um corpo animalizado}

Outra característica presente em praticamente todos os textos referentes ao negro era a constante referência à raça, definidora dos personagens. Assim é que, invariavelmente, o nome dos personagens negros era substituído por vocábulos como: o negro, o negrinho, o preto, o pretinho, a negra, a negrinha, o preto velho, a negra velha.

Era o "pertencimento" racial que situava os personagens na narrativa, ao contrário dos personagens brancos, cujas marcas raciais não eram nomeadas ao longo dos textos analisados. Pode-se analisar que a referência racial é que conferia identidade ao personagem, distinguindo-o dos demais, definindo uma alteridade.

A descrição dos personagens negros em seus atributos físicos chama atenção ao longo das narrativas. Se, por um lado, os textos buscavam marcar um ideal "integracionista" em que negros e brancos partilhavam o mesmo espaço (em posições sociais hierarquizadas), por outro, os atributos físicos dos personagens eram descritos de forma diferenciada ao se referir a negros e a brancos. Existe quase um paralelismo nos textos em que as mesmas partes do corpo sofriam denominações diferenciadas de acordo com o "pertencimento" racial dos personagens. Assim é que, enquanto o branco tinha "cabeça", o negro "carapinha, ou carapinha dura", o branco tinha "cabelo" e o negro "pixaim”, o branco possuía "lábios" e o negro "beiço", "é beiçudo, tem gengivada vermelha". 0 branco tinha "nariz" e o negro "ventas". O branco tinha "pele" e o negro era "lustroso". Da mesma forma, a branca "se sentava" a negra "se escarrapachava".

Tal paralelismo denota uma diferenciação desqualificante do negro. Ambos eram representados como corporalmente diferentes, distintos. Fica clara uma animalização do ne- gro, na medida em que a descrição do seu corpo colocava-o entre o corpo animal e o corpo do homem branco. Os textos, na verdade, reproduziam uma representação que, historicamente, fez-se presente no campo científico, ao final do século XIX, que situava o negro, no interior da cadeia evolutiva, num patamar entre o homem branco e as demais espécies (Rodrigues, 1935; Vianna, 1938).

É interessante observar que Lobato fazia referência, em diversos textos, ao beiço de Tia Nastácia, animalizando-a. Assim, por exemplo, dizia Emília, em Reinações de Narizinho:

(...) eu cortava um pedaço desse beiço. (1931, p.36)

Na mesma obra, num diálogo entre as crianças, Emília retruca Pedrinho:

(...) melado com rapadura é uma coisa de lamber os beiços, disse Pedrinho - Beiço é de boi, protestou Emília. Gente tem lábios. (1931, p. 36)

$\mathrm{Na}$ verdade, a uma suposta inferioridade estética corresponderia uma desqualificação cognitiva. Ao animalizar os personagens negros, os autores reproduziam uma representação que associava tal inferioridade a uma menor capacidade cognitiva.

\section{Tornar-se branco}

Nos textos analisados nos quais apareciam crianças brancas e negras, buscava-se marcar um ideal de integração entre os personagens, em que estes participavam das mesmas aventuras, estabelecendo-se uma suposta igualdade, apesar das diferenças étnico-sociais. Em $\mathrm{Um}$ passeio em Petizópolis, Max Yantock narrava a seguinte cena:

O Lambuza e o Milton Almofadinha desceram apressados do bonde e foram oferecer o braço à menina que continuava a agitar o lenço. Mas a menina, com um muxoxo, re- 
cusou o braço de um e de outro. Deste cavalheiro não gosto - disse ela, apontando o Milton - é um almofadinha e deste outro (apontou o Lambuza) ainda pior, não tira o dedo do nariz nem que o cortem. Apressouse um terceiro cavalheiro, o pretinho Alcaçuz. - Este, sim - disse a menina, oferecendo graciosamente o braço ao cavalheiro de chocolate - é preto por fora, mas deve ter a alma branca. (Yantock, 1935, p.17)

A fala da personagem é inequívoca. Apesar de preto, Alcaçuz tinha alma branca, o que the permitia ser aceito como companheiro pela criança branca. Fica clara a desqualificação das raízes raciais do personagem, sendo que a referência racial aparecia como um fardo compensado por seu caráter, que o "igualaria" às demais crianças brancas. É interessante observar que a pretensão do autor parecia ser transmitir a idéia de convivência, integração interracial. Mas, ao fazê-lo, despojava o personagem de sua identidade étnica, marca vexatória compensada pelo caráter moral branco.

Os negros eram destituídos de sua identidade étnico-cultural, reduzida a diferenciações físico-raciais. A possibilidade de tal convivência dava-se por meio do embranquecimento dos personagens negros, do despojamento de sua identidade racial.

$\mathrm{Na}$ verdade, faz-se presente em quase todos os textos um ideal de embranquecimento tão característico na análise sociológica das relações interraciais no Brasil. Se, no campo científico, o ideal de embranquecimento era analisado como solução para o país, ante a miscigenação característica (Oliveira Vianna, 1932), nos textos tal embranquecimento perdia seu caráter metafórico e tornava-se literal. Reproduzia-se nas diversas narrativas o embranquecimento físico dos personagens negros. Como apresenta Menotti Del Picchia no já citado No país das formigas:

Tal qual uma mosca muito preta, Pé de Moleque nadava e debatia-se num lago muito branco. A terrina estava cheia de leite (...) Banho de leite faz bem pra pele, disse o
Joãozinho que se divertia com os apuros do companheiro. Quem sabe se você sai branco daí de dentro. Depois de algum tempo, com pena do companheiro, João Peralta ajudou a safar-se. Desta vez o garoto apareceu branco... enormes pedaços de nata cobriam-lhe a cara e somente a ponta do nariz continuava preta. Você parece mágico Pé de Moleque... você há pouco estava mais preto que o gato preto do tio Moçamba, e agora está mais branco que minha camisa. (1932, p. 103)

Ou Lobato em Reinações de Narizinho:

Tia Nastácia não sei se vem. Está com vergonha, coitada, por ser preta. - Que não seja boba e venha - disse Narizinho - eu dou uma explicação ao respeitável público... Respeitável público, tenho a honra de apresentar (...) a Princesa Anastácia. Não reparem ser preta. É preta só por fora, e não de nascença. Foi uma fada que um dia a pretejou, condenando-a a ficar assim até que encontre um certo anel na barriga de um certo peixe. Então, o encanto quebrar-se-á e ela virará uma linda princesa loura. (1931, p. 206)

Lobato aproxima sua narrativa da história de Pérola da Manhã, reproduzindo mitos presentes na cultura oral, também presentes em Macunaíma de Mário de Andrade, do mesmo período. Porém, se o autor modernista buscava retratar os mitos fundadores da brasilidade, numa perspectiva crítica, Tales de Andrade e Lobato apresentavam a herança racial africana como um fardo, a desqualificar os personagens. A literatura infantil espelhava a representação social das relações interraciais no Brasil, representação em que uma visão racista e etnocên-trica fazia-se presente, escapando à idealização pretendida pelos autores das obras infantis.

\section{O embranquecimento do leitor infantil}

A ambiguidade e a ambivalência presentes nos textos que tratavam da questão racial 
demonstram o caráter que esta tomava no Brasil, no período analisado. 0 fim da escravidão não significou a ruptura com um modelo de submissão e subserviência, mas, ao mesmo tempo, a construção de um Brasil moderno significou a incorporação mitificada do negro como parte constitutiva da cultura nacional, representante de tradições e costumes que confeririam identidade ao país. 0 resgate de tais tradições não significava, na produção literária analisada, a incorporação do negro ao cenário da época, mas o remetimento de sua cultura ao passado. 0 lugar do negro no projeto de nação que se desenhava no período analisado e que era apresentado na literatura só era possível mediante a negação de suas marcas raciais, pelo embranquecimento reiteradamente descrito nas narrativas.
Por meio da análise dos diferentes retratos dos personagens negros nas obras é possível aprender a construção de uma representação do negro na literatura destinada à criança. Representação essa construída no diálogo com outras formações discursivas, como o discurso científico, que apontava, ao mesmo tempo, a visão sobre o negro na sociedade brasileira no período analisado, como indicava os modelos que se buscavam desenvolver na criança leitora. 0 leitor que os textos produziam era marcado pela identificação com a cultura e estética brancas, ao mesmo tempo que desqualificador da cultura e estética negra. Negro ou branco, os textos acabavam por embranquecer o leitor, ao reiteradamente representar a raça branca como superior.

\section{Obras analisadas}

ALMEIDA, P. Páginas infantis. São Paulo: Typografia Brasil, 1909.

ANDRADE, T. Saudade. São Paulo: Melhoramentos, 1919a.

Pérola da manhã. São Paulo: Melhoramentos, 1919b.

Bela, a verdureira. São Paulo: Melhoramentos, 1926.

BILAC, 0.; NETTO, C. Contos pátrios. Rio de Janeiro: Alves, 1904.

BRAHE, T. Histórias brasileiras. Rio de Janeiro: Quaresma, 1914.

BRANCO, L. 0 Brasil das creanças. São Paulo: [s.n.], 1927.

LOBATO, M. 0 Saci. São Paulo: Editora Nacional, 1921.

Reinações de Narizinho. São Paulo: Ed. Nacional, 1931.

Caçadas de Pedrinho. São Paulo: Ed. Nacional, 1933.

. Aritmética da Emília. São Paulo: Ed. Nacional, 1935.

Memórias da Emília. São Paulo: Ed. Nacional, 1936.

. Histórias de Tia Nastácia. São Paulo: Ed. Nacional, 1937.

PICCHIA, M. No país das formigas. São Paulo: Melhoramentos, 1932.

VELLOSO, M. As férias com a vovó. Rio de Janeiro: Alves, 1932.

YANTOCK, M. 0 lombrigoplano do professor Pipoca. São Paulo: Melhoramentos, 1935a.

. Um passeio em Petizópolis. São Paulo: Melhoramentos, 1935b. 


\section{Referências bibliográficas}

BOURDIEU, P. As regras da arte. São Paulo: Companhia das Letras, 1996.

BRADBURY, M.; Mc FARLANR, J. Modernismo: guia geral. São Paulo: Companhia das Letras, 1989.

CHARTIER, R. A história cultural. Lisboa: Difel, 1990.

COELHO, N. Dicionário crítico de literatura infantil e juvenil brasileira. São Paulo: Quiron, 1981.

ECO, U. Lector in fábula. São Paulo: Perspectiva, 1986.

FRACCAROLI, L. Bibliografia de literatura infantil em língua portuguesa. São Paulo: Prefeitura de São Paulo, 1953.

FREYRE, G. Casa-grande \& senzala. Rio de Janeiro: José Olympio, 1933.

GERKEN, C. H.; GOUVEA, M. C. Imagens do outro: a criança e o primitivo nas ciências humanas. Educação em Revista. Belo Horizonte: UFMG, n. esp., set. 2000.

GOUVEA, M. C. S. 0 mundo da criança: a construção do infantil na literatura brasileira. Bragança: São Francisco, 2004.

LAJOLO, M.; ZILBERMAN, R. Literatura infantil brasileira. São Paulo: Ática, 1985.

PERRONE-MOYSÉS, L. Flores da escrivaninha. São Paulo: Companhia das Letras, 1990.

RODRIGUES, N. Os africanos no Brasil. 2. ed.São Paulo: Companhia Editora Nacional, 1935.

SEVCENKO, N. Orfeu extático na metrópole. São Paulo: Companhia das Letras, 1992.

VIANNA, O. Evolução do povo brasileiro. 2. ed.. São Paulo: Companhia Editora Nacional, 1938.

Recebido em 02.03.04

Modificado em 10.02.05

Aprovado em 03.03.05

Maria Cristina Soares de Gouvêa é professora da Faculdade de Educação e do Programa de Pós-Graduação em Educação da UFMG, pesquisadora do Grupo de Estudos e Pesquisas em História da Educação (GEPHE) e bolsista de produtividade do CNPq. 